The University of San Francisco

USF Scholarship: a digital repository @ Gleeson Library |

Geschke Center

Media Studies

College of Arts and Sciences

2005

\title{
The Whole World is Watching Us: Music Television Audiences in India
}

Vamsee Juluri

University of San Francisco, juluri@usfca.edu

Follow this and additional works at: http://repository.usfca.edu/ms

Part of the Film and Media Studies Commons

\section{Recommended Citation}

Juluri, V. (2005) The Whole World is Watching Us: Music Television Audiences in India, in J. N. Erni and S. K. Chua (Eds.), Asian Media Studies: Politics of Subjectivities (161-182). Blackwell Publishing Ltd [Wiley], Oxford, UK. ISBN: 9780631234982.

This Book Chapter is brought to you for free and open access by the College of Arts and Sciences at USF Scholarship: a digital repository @ Gleeson Library | Geschke Center. It has been accepted for inclusion in Media Studies by an authorized administrator of USF Scholarship: a digital repository @ Gleeson Library | Geschke Center. For more information, please contact repository@usfca.edu. 


\section{The Whole World is Watching Us: Music Television Audiences in India}

\section{Vamsee Juluri}

\section{Introduction}

In an essay on the possibilities for media studies as a public intellectual practice in India, Dipankar Sinha (2000) notes with some irony that the critical discourse on media and cultural imperialism has become less visible precisely at the time that it is perhaps most needed. During the 1990s, the Indian mediascape went through a remarkable set of transformations as a powerful set of transnational and national forces under the twin labels of globalization and liberalization transplanted people in India from a singlenetwork television environment to one of multichannel, 24-hour satellite broadcasting. If the rapidity and intensity of the social and cultural fluxes generated by the advent of satellite television in India seemed breathtaking, a greater surprise - especially for media scholars - would be the seeming normalcy into which these fluxes and transformations apparently disappeared. In other words, even as "cultural imperialism" was a rather commonplace concern in the Indian public sphere until the 1990s, by the end of the decade it seemed to have hardly the kind of currency one would expect it to have in the face of all the new challenges.

For example, in the early 1990s, a frequent question in graduate and postgraduate competitive examinations used to be about "cultural imperialism" in the context of the rise of satellite television in India (the other popular question as I recall pertained to the role of India and NonAlignment in the post-Cold War world). Among my colleagues and fellow journalism trainees at that time, opinion used to be intelligently divided 
on this issue. Some of us appreciated the seriousness of what was happening, although we felt compelled to distance our critique from what seemed like an ancient and paternalistic critique coming from traditional quarters (retired public officials, ministers, sinecured public commentators). Some of us simply scorned the notion of a critique altogether, arguing that satellite television would be merely another harmless play-thing for Indian elites, who were all "Westernized" in some form anyway. In either case, we had been taught all about NWICO, and the tradition, and knew what "cultural imperialism" referred to. In 1997, as I conducted my interviews for my dissertation research, I was surprised to find that most of the participants - many of whom were well-informed and articulate students - said that they had never heard of the notion of "cultural imperialism." They all had heard of "globalization," though.

In this chapter, I discuss the state of Indian media studies at a moment when the inexorability of globalization confronts the inadequacies of prior critique as exemplified in the notion of cultural imperialism, and evaluate the growing importance of audience studies as a response to this moment. I argue that audience studies are important not only as a way of broadening the terms of analysis of media in India, but also as a way for Indian media studies to politicize its own international location in relation to the subdisciplinary tensions and polarities of media studies which in the Western academy have long been manifested as a needless opposition between the "cultural imperialism" tradition on the one hand and the "audience studies" projects on the other. In both these intellectual contexts, my aim is to show that attention to audience research in the postsatellitetelevision era in India can serve to strengthen a critical approach to media globalization that is rooted in what Ashis Nandy (1998) characterizes as simultaneously a "critical cosmopolitanism" as well as a "critical traditionalism."

Such a move is warranted not only by the particular intellectual and institutional politics of Indian media studies, but more importantly by the fact that the dominant feature of the postliberalization national social imaginary in India seems to be one of the complete opposite. One of the most pervasive television genres that has emerged in India since 1991 is music television, and its dominant theme may be summarized as one of an uncritical global-nationalism. While international music-television giants such as MTV and Channel V entered the Indian market with localization as their entry ticket, the rise of numerous Indian music-television channels and programs as well have all served to create a popular television discourse about being "Indian" in the age of globalization. For instance, one of the 
most popular music videos of the 1990s in India was Alisha Chinai's "Made in India," which shows a princess turning down suitors from different nations and finally choosing a man who is "made in India." Later in the decade, the self-deprecating slogan "world famous ... in India" became well known on music-television promos. Music television, in short, promised a renewed sense of national identity in a rapidly globalizing context. But as I show in this chapter, on the basis of my own reception studies of music television in India, the global-national that is emerging among the middleclass Indian television audience is more a case of appropriation rather than a cause for celebration. Using the readings made by young middle-class music television viewers of "Made in India," I argue that the perception among these viewers of globalization as a process of international empowerment and recognition for India must be seen as neither simple audience victimization nor resistance, but instead as a site of epistemic struggle, and indeed domination, that media studies in India must confront.

It is my contention that these questions about Indian media and Indian media studies warrant closer attention to the notion of the audience - not only as a methodological step towards other analysis, but as a valid object of study in itself. It is useful, in other words, to conceive of the audience in this case the satellite television audience in India - not merely as the endpoint of media transmission, but more accurately along three dimensions: (a) the role it occupies in the constitutive "imagination" and measurement of desired audiences by media institutions (the first instance of political economy in which the audience is constituted in terms of purchasing power), or, in other words, how MTV (and others) built their audience in India; (b) the audience as it emerges from the textual implications of programming (what sort of demands do these new genres and programs place on audiences in order for them to "get" the meaning?); and (c) under what constraints, with what expectations, and with what possible consequences do people "become" audiences (the ethnographic moment)? It is my contention that Indian media studies have usefully engaged with the first and second moments described above (even if not always explicitly with the audience as a problematic), while the contours of actual reception particularly in the context of satellite television - are only beginning to be addressed. The reasons for this particular configuration of research priorities, and the growing need for audience research, as I argue, are not incidental, but central to how the projects and formations of "Indian media studies" are implicated in a politics of epistemologies and institutions that seem well described by Arjun Appadurai's (2000) characterization as the "knowledge of globalization" and the "globalization of knowledge." 


\section{Indian Media Studies}

Despite the characterization for analytical and polemical purposes of the kind of work I address in this chapter as "Indian," it is useful to note the transnational continuities (and tensions) that mark the development of the study of media in the broadest sense in the (ex)colonies and the metropolitan Western academy. It is important not to think of media studies in postcolonial contexts as merely an import; a mere benediction sent around to help those who have already been plunged into saturated media conditions lead better lives (or worse, figure out more efficient ways of making the media more pervasive and commercially successful). However, the institutional history of media studies in India may be usefully located in a global context that in a sense precedes the present-day context of advanced (and media-rich) globalization. Vasudeva and Chakravarty (1989) show that the institution of "mass-communication research" in India in the 1960s was implicated in the tensions of what was then the dominant tendency in international mass-communication research - the development communication and modernization paradigm. In other words, rather than dismiss this institution as a unidirectional imposition of Western thinking on the postcolonial context, it is also useful to see how the "Nehruvian" era that was so fundamental in its impact on masscommunication research was itself both national and international in its outlook.

While it is true that "national development" was often the unquestioned goal for the institution of mass-communication research (and training the vocational thrust was, to be fair, perhaps what was considered most important), the assumption of modern/Western goals of modernization at the social and epistemological levels was articulated to the desire for national sovereignty; in addition, the nationalist position was also evident not in any kind of an isolationist, insular, thinking, but also situated in the context of a growing feeling of third-world anti-imperialist solidarity. So even if Wilbur Schramm went around setting up national institutes of mass communication in various countries (my own experience of this was curiously surprising, when I met in the US someone from Kenya who had been through exactly the same kind of journalism program I had been through in India), this was also an opportunity for actual interaction between postcolonial nations. The Indian Institute of Mass Communication in New Delhi, for instance, offered in addition to its various training programs for communication officers in the government, an advanced program for professional news reporters from Non-Aligned nations. 
By the time of the rise of satellite television and liberalization, masscommunication research in India was taking on a number of challenges, not only from the urgency of the questions at hand (ranging from policy issues to curricular responses to meet a growing demand for professionals, particularly in the private-sector media), but also from the scholarship of nonresident Indian scholars, foreign-trained scholars, and local scholars with a critical orientation that was bringing in - in some form - the concerns of a critical cultural-studies approach to contemporary media studies. In the 1990s, as Sinha (2000) writes, there was a general increase in concern and visibility for media studies in India, ranging from curricular recognition (although, as he notes, the study of the "information age" needs to be included not only in mass-communication and journalism curricula but broader social science subjects as well) and policy recommendations to the growing presence of public commentary on media and culture in the press, and to some extent, television as well. ${ }^{1}$ However, as Sinha points out, there still remains some unproductive divergence between the "traditional" or "mainstream" mass-communication research approach and the more nuanced but not always politically engaged "mediastudies" approaches.

In particular, Sinha says that while the mainstream studies of mass communication in India (which, he laments, have not been too many in the first place) may have been somewhat "factual" and "technocratic," the cultural-studies oriented media studies have been "inward looking" and unable to engage with the connections between "textuality and subjectivity" on the one hand, and the broader politics of these on the other (2000: 4190). Sinha qualifies his critique by saying that it is not necessarily the fault of the nonresident Indian scholar that cultural studies of media in India have been unable to grapple with the politics as effectively as they do with the nuances of meaning and everyday life, especially in the shadow of Indian popular culture. Following Sinha's critique, one may usefully turn to the broader "politics of location" in communication studies in general, and how this has a bearing on what sort of studies do get conducted. More importantly, the question of whether media studies in India has the force and potential to do justice to the severity of its object of study needs to be addressed in this context. As Sinha points out, the possibilities for Indian media studies lie not only in terms of making the right methodological decisions, but more importantly by responding and remaking media studies with a suitable "local" epistemological focus that is appropriate to the global scope of its analysis. In other words, what would make for an "Indian" media studies in an age of "global" media? In this chapter, I 
examine how audience studies could respond to such a challenge, particularly by engaging with epistemic issues in reception in both "local" (or national) and "global" ways.

\section{Globalization and Audience Studies}

The tensions between the global and the national are as relevant in media studies as they are in media institutions. If the national was taken as the unit of development quite literally in traditional international mass-communication research (national integration, national development), the role of the national in the new globalizing project of media studies raises new questions, particularly in terms of the question of the audience. Has the rise of audience studies in the West found a response in the Indian context? What are the problems and constraints facing engagement with Indian audiences because of the institutional politics of audience studies in terms of its Western location and nascent Indian institutional parallels? Most importantly, why is the audience important to Indian media studies, and what are the possibilities for an "Indian" epistemological thrust to such a project?

The importance of audience studies to the Indian and global contexts comes from a number of factors. Within India, even the spate of scholarship that has emerged since the rise of satellite television in the 1990s has taken mostly a political-economy, institutional, policy-oriented, or at best, textual-analysis approach. ${ }^{2}$ All the while, the most remarkable transformation was taking place on the ground in terms of the experience of hundreds of millions of people as television audiences, and global audiences, in some ways. The need for audience studies, however, comes not only from the urgency of this transformation, but also from the enduring significance of the "audience" as an object of study in media studies, and particularly the demands for attention for audience studies raised by recent developments in the globalization of media and media studies. As I have argued elsewhere (Juluri, 1998; 2003) the rise of interest in audiences since the spread of critical cultural-studies mandated work on media in metropolitan nations since the 1970s has been met by a new set of impasses in dealing with nonmetropolitan contexts. Briefly, my contention vis-à-vis the politics of global media/cultural studies is that the postmodernist turn in audience theories and what Nightingale (1996) calls "cultural studies audience research" has been disenfranchising for audience studies and media studies in, on, and from nonmetropolitan contexts. While the rise of audience studies in 
cultural studies has clearly drawn due attention to the need to engage with the experiences of people in relation to media (rather than assume effects either from institutional analyses or from textual studies), a more recent tendency, as I have argued, has been to emphasize the unknowability of audiences as a rigorous global condition. In other words, an otherwise welcome critique of the presumptuousness and power implications of knowledge-claims embedded in institutional discourses about audiences has translated into a sense of defeat for the whole purpose of audience studies (see Ang, 1996).

Such a tendency becomes especially problematic when scholars from and working on nonmetropolitan contexts seek to address the experiences of audiences within media studies as a global and anti-imperialistic project. Thus, even if postmodern critiques of Western audiences rightly emphasize the limited nature of their ability to "know" audiences, the tendency to conflate this criticism with an overarching positing of unknowability of audiences and, by extension, lack of necessity for audience studies wipes out precisely those calls for marginal and nonmetropolitan voices that such critiques have sought to highlight. As R. Radhakrishnan (1994) has argued in his influential essay, "Postmodernism and the Rest of the World," the emphasis on relativism and openness that the postmodern critique of the Western episteme has sought to raise has itself become an absolute and totalizing condition, thanks to continuing dominance of the institutional structures of the Western academy on a global scale. The place of nonWestern audience studies, in other words, is condemned to a mere afterthought to the canon of cultural-studies audience research, always having to apologize for its limitedness and supposed epistemic faults at worst; or having to qualify itself as a "marked" project: in other words, such audience studies tend to become sorted into categories such as "Asian" or "Indian" projects, while the very "British" or "American" audience studies are seldom marked that way, and enjoy the career of universal, unnamed normativity even if their specific authors do not make such claims.

These tendencies have been rightfully criticized within audience studies from a number of quarters. While postcolonialist media ethnographers like Natrajan and Parameswaran (1997) have argued that an actual engagement by researchers with non-Western audiences in their everyday contexts is necessary and cannot be done away with merely by recourse to more selfreflexive writing strategies by ethnographers, some audience researchers have also been assertive about the need for actual empirical audience research to supplement if not supplant both textually derived media analyses (Stromer-Galley \& Schiappa, 1998) and the broader politics of "pop- 
ulism" in media ethnographies (Gibson, 2000). In addition to these critiques, the need to restore and claim a place for audience studies in non-Western contexts also arises from what is perhaps a foundational justification for audience studies in general: the paramount importance of engaging with issues of determination and power in media studies. The metatheoretical, self-reflexive critique of issues of power in the institutional practices of media studies set two goals for global audience studies: (1) that the "global" be taken seriously, with all its attendant implications for universalist ambitions that are driven by a critique of Eurocentric universalism while not losing sight of the possibility of alternative universalisms (Chen, 1998); and (2) that there is equally the need to forward theories of media determination based on engagement outside the academy with what is actually happening in the lives of people in relation to the media. Although the mandate and constraints of cultural-studies audience research imply that its conception of determination is not a simple unilinear one of either behavioral lines of effect from media to audiences (or functionalistic forces from audiences to media), the core concern for these studies, and I believe for audience studies in India, as I will show below, is the question of how "unnatural" power relations in the social formation come to be "normalized" through the process of reception. In other words, the central importance of audience studies comes not only from a need to include "other" voices in the debate, but to map out the ways in which how people become audiences - particularly in non-Western contexts - embodies the workings of cultural power in the broadest social and historical sense. In other words, what role do the media play in bringing audiences into a condition of hegemony - especially since "hegemony" needs to be thought of increasingly at the subnational and transnational levels as well? What would a sufficiently globalist critical approach to audience studies need to do in order to engage theoretically and politically with such a project? Finally, what role can be found for non-Western and nonmodern epistemologies in reception in such a project?

\section{Audience Studies in India}

Audience studies "in" and "on" India that have engaged with issues of power in this sense have not been numerous, but are nonetheless important and useful in engaging with the broad transformatory sweeps that have brought large populations via their construction and interpellation as audiences into various levels and forms of hegemony. In this section, I outline some 
of these projects, and then go on to address some of the questions raised by the rise of satellite television, and particularly music television in India, about the transnational and transgenerational aspects of hegemony that I have addressed in my own work.

The possibilities of audience studies in India have been demonstrated perhaps most notably in the ethnographic study conducted by Purnima Mankekar (1999) into the lives of women television viewers of Indian state television in the late 1980s. Mankekar's study engages with an important moment in Indian cultural politics and media that has both preceded and enabled the present-day problems of globalization that I address later in this chapter. The rise of a pro-capitalist Hindu right-wing political movement in India in the 1980s has been widely related to the popular success of two "religious" serials broadcast nationally on Doordarshan, the stateowned television network, during that time (see Rajagopal, 2000). These epic serials, the Ramayana and Mahabharatha, not only "centralized" what had earlier been a fairly regional and pluralistic set of popular sensibilities, but also did these within the shadow of increasing commercialization of state television on the one hand and the broader rise of a politically assertive and culturally fundamentalist middle class on the other. Mankekar's work, however, takes these issues "home" quite literally, not only in terms of the gendered nature of the reception of these programs and their translation into the emerging relations of power in the Indian context, but also outlines some epistemic possibilities in reception that some may say are distinctly "Indian" in their difference from Western/ modern epistemes - but which could equally usefully be interpreted as the core of an alternative universalistic episteme as I will show later in this chapter.

Such possibilities are also evident in the ethnographic study of poor, urban South Indian viewers of Tamil cinema by Sara Dickey (1996). Dickey's engagement with what has for long been the core audience in class terms of Indian cinema shows that the pervasive importance of cinema in their lives must be seen neither as their victimization by middle-class producers of escapist fantasies nor as a valiant reappropriation by resistive consumers. Instead, Dickey points out that the borderline of these two opposite forces is what constitutes the hegemonic moment of Indian cinema in the lives of its poor audiences - and this borderline is cast, importantly, in terms of the identification of viewers with the familial, relational, and emotional aspects of the narratives of Tamil films. In other words, even if Indian cinema with all its melodramatic grandeur and escapist fantasies perpetrates and perpetuates an interclass hegemony (poor viewers identifying 
with the lives of rich characters and sometimes even richer film stars), it is important that this identification takes place within the lines of familial identities and relationships. On the basis of my study, I will show later in this chapter how this particular tendency to foreground familial identifications in Indian media reception also constitutes a set of possibilities for an alternative epistemic sensibility and universalism in understanding audiences.

More recently, since the rise of satellite television and the broader media boom entailed by economic liberalization in India, media research and media research institutions have also sought to engage critically with the present moment. The work of Melissa Butcher on youth audiences and images of beauty and the body in Indian television (1999) has skillfully highlighted how the particularly visual aspect of television may be theorized in terms of reception. In other words, Butcher has shown how television audiences are becoming implicated not only in emerging forms of "looking" Indian, for instance, but also in how these visual forms constitute a new way of "knowing" one's self, as an "Indian," among other things. While Butcher's work has enriched traditional audience research issues such as comprehension, recognition, and pleasure with questions about the body, a more direct engagement with a quite literal bodily disciplinarity and power is evident in the ethnographic work being conducted by members of the Center for the Study of Culture and Society on Dalit (formerly "untouchable") viewers of South Indian cinema. ${ }^{3}$ Their study addresses how cinema viewing rituals surrounding first-day shows of new releases and their negotiation by young, male, working-class fanclub members is marked by literal struggles over their bodies and activities by theater management and various disciplinary apparatuses.

As these four examples illustrate, audience studies in India are beginning to engage with a previously neglected area in media studies, but are also pointing out new and important lines of theorizing in audience studies that do not have to be perforce limited in their usefulness to "Indian" or "local" contexts. In the following sections, I outline how such lines of theorizing may emerge on the basis of one issue that has not yet been addressed - the epistemic politics surrounding audience identification with notions of the national and the global in the reception of Indian music television. In particular, I discuss how the experience of becoming a global audience through the reception of music television in India may point out not only the complexities of hegemony under the present moment of globalization, but also highlight some of the epistemic possibilities that may be claimed counterhegemonically not only as "Indian," but as "global" as well. 


\section{Global Audiences: Indian Music Television}

The rise of satellite television in India has been dominated by one kind of programming perhaps more than any other - music television. In addition to the international music television channels such as Channel V and MTV, music television is widely watched in India through Indian music television channels such as Music Asia, as well as on a plethora of family/entertainment-oriented national and regional language channels. My study of music television audiences (Juluri, 2003) seeks to answer how and why music television (which may be summarily described here as consisting largely of Indian film songs and pop-music videos in a Western- or MTVstyle format) has come to dominate postliberalization television in India, and some of its implications for audiences, particularly in terms of their negotiation of the meanings of nationality and globality pervasive in many music television programs. My concern has been not so much with the globality (or worldwideness) of music television or MTV itself, but more so with the globality of audiences in relation to music television; in other words, what meanings do audiences construct about themselves and their place in the world (as national subjects among other things) particularly in terms of how they read certain popular music-video texts that explicitly address "global" themes? As I argue in the following sections, what emerges from the reception of music videos in India is neither a case of simple cultural imperialism nor one of audience resistance, but instead a set of possibilities for understanding an alternative epistemic world that is being increasingly appropriated by the discourses of music television.

At the outset, it is useful to spell out why audience research was needed particularly in the context of this study. Theoretically speaking, in addition to the arguments with the literature described earlier in this chapter, there has been another fallacious tendency among cultural-imperialism theories to posit audience studies as somehow antithetical to the critique of media imperialism (see Roach, 1997). Despite the claims of even sophisticated theorists of media globalization like Tomlinson (1991) that audience studies can do little but confirm audience activity against assumptions of media imperialism, it is worth reiterating that it is perhaps through audience studies that media power can be best appreciated. In addition, the empirical reality of media globalization in India also complicates a simple assumption of cultural imperialism as the influx of Western media and culture. After a brief period of largely American programming, most satellite television channels have localized extensively in India. Both MTV and Channel V, for instance, frequently claim to be more "Indian" than the 
other. ${ }^{4}$ Thus, even if satellite television is "Western" at the level of ownership, it is clear as Chadha and Kavoori (2000) argue, that the bulk of popular programming in India, and much of Asia, has been localized.

From the audience perspective, the localization strategy of music television has emerged as a widespread celebration of national identity in a global context. One of the first music videos in India was Alisha Chinai's "Made in India," which promoted what would become one of the first commercially successful nonfilm music albums in India. ${ }^{5}$ The popular resonance of "Made in India" continued in Indian pop and film songs all through the 1990s, culminating in a sense in a spate of releases to commemorate the fiftieth anniversary of India's independence in 1997. The celebration of Indian identity by the Indian music and music television industry, however, may be attributed to a more careful cultivation of youth markets in India. Market researchers have sought to position a youth market that is clearly defined in generational terms mainly in terms of its particular experience of Indian national identity - a consuming, postliberalization generation as it were, "rebelling in" to the middle class world that its parents had earlier avoided with their values of "Nehruvian austerity."

For music television channels like Channel V and MTV, the cultivation of the youth audience took place along two important axes, both of which warrant the necessity of audience studies: one, following the dictum that "Indian inside/Western outside" had strong appeal to Indian audiences, these channels positioned themselves as global-Indian in a range of ways; two, given the absence of two-TV-set households and the attendant lack of a clearly demarcated presence of independent youth viewers, Channel V sought to construct a broadly transgenerational audience, calling itself a "youth channel in attitude but a family channel in demographics." In other words, the youth culture of music television in India was positioned to be both global and Indian, and cool enough for youth but not offensive enough for parents to vociferously object. It is also worth noting on this point that despite the incidents of intolerance and violence directed against artists and intellectuals by portions of the Hindu right wing, MTV and Channel V have hardly been the object of any anger from fundamentalist groups in India. On the contrary, Michael Jackson's concert in Mumbai a few years ago was organized at the behest of the leader of the right-wing Shiv Sena party.

My study of the reception of music television addressed a number of themes, but what is perhaps more relevant to this essay is the negotiation of meanings around music videos with explicitly nationalistic themes. The following excerpts are drawn from participant readings of "Made in India," as 
well as some broader observations made by participants about their experience and understanding of globalization and satellite television in general. The interviews from which the following excerpts are culled took place in the south Indian city of Hyderabad in 1997. Participants were mostly middleclass high school and college students, and young professionals or postgraduate researchers. The interviews were structured around the viewing of a number of video clips, and were conducted in a mixture of English, Hindi, and Telugu (the regional language). Although most participants were largely viewers of national and regional language channels (MTV and Channel V were closely watched only by a small number of them), what was striking was the extent to which themes of globalization emerged from even exclusive viewers of regional language channels like Gemini and ETV. As the following section shows, the experience of globalization and national identity for these participants reveals contours of reception that not only surprise easy assumptions about globalization, but also highlight the need to address epistemic issues in the everyday construction of globality.

\section{Made in India}

The narrative of "Made in India" perhaps best summarizes what has emerged as the popular story about the experience of globalization in India. While the experience of globalization in everyday life in India may include such phenomena as friends and relatives going abroad to study or work, an increasing presence of consumer commodities (such as Kellogg's Basmati Flakes), and, of course, the internet and satellite television, the popular resonance of "Made in India" since its release in 1994 perhaps best summarizes the way a set of myths have caught hold of the emerging Indian global imagination. The story of the song, briefly, revolves around the languid wait of a fairytale princess called Alisha who turns down a series of "global" suitors while the lyrics of the song describe her desire for a "heart made in India." In the end, her dream suitor appears, carried into her court in a box marked "Made in India." In addition to the obvious importance accorded to the national and the global in this song, it is also worth noting at the outset the visual character of the video, and the particularly orientalistic images used to suggest a combination of exotic Indianness and generic fairytale-ness (elephants, snake charmers, yoga practitioners, magicians, tigers).

The popular appeal of this song arguably represents what many Indians would like to think of themselves in terms of their place in an increasingly 
globalizing world. While the song may appear to be an example of jingoistic nationalism right at the outset, it is interesting that, at least in the course of my study, audience readings of this video showed a more complex engagement with the meanings of this song, and the meanings of globality and nationality in general (although this complexity is no sign of audience resistance, as I argue later). At the outset, "Made in India" was clearly familiar and well-liked by most participants in my study, and its appeal was certainly not confined to Hindi speakers or MTV viewers, as the following statement by an older, professional, middle-class person shows:

I thought that from the song, it talks about culture, our Indian culture. Something, saying that "Made in India," "Made in India." At the same time they are showing clippings of Kathakali [classical dance] arts which are famous in India. At the same time, they are comparing with Western also, with Japan, Russia, like that. Actually, I can't understand the full meaning of the song. I am very poor in Hindi. But I like this song. Why? Because the music was good, the visual was also very good.

The association of "Made in India" with a sense of Indian culture, however, was not merely a recollection of some stockpile of "Indian" imagery for participants, but seemed to represent a somewhat deeply felt sense of being Indian. Specifically, as the following statements show, at least two participants sought to convey the observation that "Made in India" was a representation of who they really were - as Indians - rather than a sloganistic injunction to "love the country" (as they thought state television often told them to do).

["Made in India" is] not a "patriotic" song, but has a lot of meaning in it.

... they [state TV] tell us about worshipping the nation, but not about the feeling, the Indian feeling. [translated from Telugu]

The notion of the "Indian feeling" was also expressed by a number of participants through the Hindi word "dil" or the Telugu word "manassu" (both of which could be translated as "heart" without implying a "head/heart" distinction). Despite the rather simplistic use of dil in the lyrics of the song, it is interesting that participants engaged with this notion in various ways, most notably, in terms of relational values. For instance, when asked to clarify what being Indian or having an Indian "heart" meant to them, some participants said that it meant having a "good character," or being a "good husband," or being "respectful to elders." In other words, despite the broader 
media construction of Indian greatness in a global context in terms of commercial and military success, ${ }^{8}$ it is useful to note that there is a sense of national identity expressed in everyday interpersonal terms as well, at least in relation to this video. While it may be easy to criticize these statements as being nothing more than a more nuanced interpretation of the sloganeering of the music video, it is perhaps more accurate to think of audience readings as going beyond such textual parameters as well (although this does mitigate a critique of media culpability in this context, as I show in the following section). Simply put, it appears that participants do not merely accept the notion of Indian greatness in this song and express it in relational terms, but actually get into the nuances of the narrative, which imply at the outset a setting up of Indianness in a competitive global market of "husbands" and "hearts," as it were. As the following comment by a female middle-class high-school student shows, Alisha is seen as choosing an Indian man not necessarily because he is Indian, but because he happens to have the "qualities" that she is looking for:

She wants a person from anywhere in the world, any corner in the world, but that person should possess the qualities she wants.

In other words, "Made in India" is not seen as directly exhorting Indian superiority, but merely pointing out that it in a fair and competitive marketplace an Indian may come out the winner. From this example, it would appear that despite the many critiques that could be raised at the institutional (a foreign-owned media corporation now provides national identification for Indians) and textual (India signified through orientalistic images) levels, audience readings are reassuring to the extent that participants combine what could be considered a nonmodern sense of community values with a modern and self-reflexive openness about their place in the world to express their feelings in this regard. However, on closer examination, especially in relation to broader media discourses about globalization and national identity in India as well as participants' perceptions of their national location in a global context in relation to media, a strong critique of media and cultural imperialism would seem well in order. As I show in the following section, the success of "Made in India" and numerous other film songs and music videos celebrating India in the global context (for example, the Hindi film songs, "East or West, India is the Best"; "I love my India"; and the pop song, "I'm an Indian") all may be related to an emerging but inaccurate perception of what exactly becoming global entails for Indians and Indian audiences. Furthermore, this perception is 
troubling not only because of its mythic quality and its embeddedness in a social context of globalization that is far from favorable to India in the way participants may like to think it is, but also because it represents, at an epistemic level, an appropriation of all that may be valued and commendable in everyday common sense by the discursive regime of the new musictelevision world.

\section{Conclusion: The Whole World is Watching Us}

In relation to "Made in India," and satellite television in general, there seems to be a perception among some participants that "globalization" represents not so much an influx of Western culture into India, but instead an outward spread - and a growing recognition of such a spread - of India and Indians into the global sphere. This perception is inflected at various levels. For instance, in the following example, the participant, a postdoctoral researcher, rightly notes that "Made in India" was made for the NonResident Indian market, and that (what was perceived to be) the successful presence of Indians in other countries shows how "Indian culture" is being recognized for its greatness all over the world:

Basically this song, when it was thought of and made, it was aimed towards NRIs [Non-Resident Indians] ... I don't think I'm 100\% correct but they wanted to show this video, this video was specifically made for NRIs and in US it made good sales and review manchiga ochindi [was positive] ... it reminds me of Indian soil. Made in India. Something made in India.

While such positive evaluations of "Made in India" as a symbol of Indian pride in the global context are fairly widespread among participant readings, what is worth emphasizing is also a sense, even if this is not exactly widely echoed in this study, that the images used to represent India need to be selected more carefully, given the fact that "others" (non-Indians) may be watching them. The following participant, who is a graduate student of classical dance, laments the fact that some of the dancers in the "Made in India" video are wearing what she considers to be objectionable ("sleeveless") costumes, as opposed to what she knows to be more authentic or accurate costumes for such dancers:

But regarding the Kuchipudi [classical dance] they are not clear, the dress is not pucca [perfect] traditional way in which other girls are wearing. Because 


\section{The Whole World is Watching Us}

when the layman abroad, they see, they think that this is a particular dress you're wearing in India but that's not true.

Despite this one exception, it is important that participants in general do not problematize the clearly orientalistic images used to represent India in this video about Indian greatness. It may be the case that these images, on the other hand, serve to reinforce the misperception that whatever Indian television audiences watch is also being seen by viewers around the world. On this note, it is also worth emphasizing that the orientalism of "Made in India" is by no means peculiar to this one video, and is a pervasive phenomenon on music television: numerous videos and promos exoticize Indian everyday life, and Indian working-class people in particular. The sort of "global" identity being sold by music television programs is therefore connected to an emerging self-perception as a global audience not so much in the usual terms of watching Baywatch, but instead in an assumption that becoming a global audience means that the rest of the world is watching Indian programs as well. The following comment by a young middle-class participant summarizes this perception:

Like Star TV is okay [not surprising as an example of a global channel] but for example Zee TV. Basically it was Indian but now we get the feeling that that they are showing our programs to Europe, US, everywhere it's being shown.

The self-consciousness as a global audience is, however, inflected in numerous other ways as well. For instance, the following participant, talking in the context of the binational image of various Channel V VJs, notes that the "foreign accent" of some of these VJs may be understandable, given the presence of viewers outside India as well:

If they're going to talk in English accent [or] Indian accent, I don't think Thailand people or Philippine people are going to follow it ... because it's basically Asian channel, not Indian channel.

However, the same participant also downplays the extent to which television can "globalize" audiences:

As soon as I switch off the TV it goes off. And I forget about everything and become Indian ... so how you become part of the international audience? You are sitting in India and watching on Indian TV. 
Thus, the "mythic" perception of global audiencehood is clearly one among others. However, the key issue is not so much whether those participants who "know" better may be more "resistive" than those who are not, but the whole question of what it means to be "in the know" in order to make meaning from music television discourses about globalization and national identity in the first place. Participants in this study were segmented not only in terms of their access to various kinds of global satellite television programs, but also in terms of their ability to engage with such discourses. Specifically, older middle-class participants, and working-class participants, did not seem to "get" the meaning of the various discourses about television and globalization (although they were familiar with the programs and the film songs and music videos in question). Although I would not reduce the distribution of cultural competences to their class (or age) backgrounds, it is worth examining the similarities and differences between those who assume a certain kind of prior knowledge in talking about (and talking to) certain discourses and those who do not.

One fundamental similarity that was apparent in the way participants talked about music television in this study was their emphasis on the relational and emotional aspects of the songs they watched. For instance, MTV-familiar viewers stressed these aspects of "Made in India," while working-class mothers stressed the same aspects about the regional-language film songs they watched. While this does not imply that "emotional" expression plays the same role given the material differences in access to privilege for these participants, it is clear that MTV viewers have not ignored such aspects of reception. However, working-class participants, and some middle-class participants, clearly do not find many other discourses surrounding these programs meaningful or perhaps even intelligible, while most young middle-class participants clearly engage with them in a meaningful and sometimes personally invested way. As I have argued elsewhere (Juluri, 2003), this difference may be described as one in which different sorts of authority to speak are claimed while speaking as an audience (see McKinley, 1997). Those who are in the know speak about their emotional experiences and relational values but speak from their modern, discursive authority as knowledgeable subjects. Those who are not in the know, speak about and perhaps from their own emotional experiences and relational values, but do not have the ability to claim any other kind of epistemic authority.

In other words, becoming a global audience - getting to be in the know so as to derive the full meaning and pleasure from music television in this context - may be seen as a process in which a certain set of experiences and 
values is increasingly marginalized for its epistemic authority, while the only source of epistemic authority becomes the discourse of music television - with all its attendant orientalistic premises. The outcome of such a process, arguably, is the naturalization of alien and imperialistic images into authentic representations; of Indianness, of the world even. Once a certain kind of representation becomes naturalized, not expressing one's self through such representations may become tantamount to not feeling or being that which is represented. For instance, 10 years ago, it was not considered commonsensical to advertise one's supposed Indianness (through songs, T-shirts, bumper stickers, and so on), but in the present discursive climate, not doing so may actually make someone appear unIndian or unpatriotic - a condition eminently suitable for the fascistic thinking that has become "normal" common sense for many middle-class, educated Indians in recent years.

The problem with this phenomenon, however, is not so much only the appropriation of an arguably commendable epistemic universe (built around relational values and emotional experience) for the naturalization of an emerging social and political order, but the fact that the universalistic possibilities that may have existed for such an epistemic universe are increasingly marginalized. The process of becoming a global audience, in other words, represents a new and more dangerously widespread phase in what Ashis Nandy (1983) has described as the tension between definition and nondefinition since colonial times. The future of audience studies in India, not only as Indian audience studies, but as a broader globalist project, may be useful for demonstrating how the epistemic possibilities found in reception may actually represent another common sense, which is neither exclusively "Indian" nor "traditional," but rooted in both and yet capable of contemporary cosmopolitanism. The new cosmopolitanism, in other words, must come from neither the development/modernization desire to enlighten backward third-world populations despite their "cultural" baggage, nor from the orientalistic hybridity of MTV, but from a certain kind of a relational sensibility that needs to be claimed by scholars and others as the bedrock of the global condition and also as a possibility for an alternative globality.

\section{Acknowledgments}

I wish to acknowledge Sanjay Asthana for his help in mapping the Indian media-studies projects mentioned in this essay. 


\section{Vamsee Juluri}

\section{Notes}

1 The work of the Bangalore-based Center for the Study of Society and Culture (www.cscsban.org), the New Delhi-based Media Foundation (www.thehoot.org), and the New York-based South Asian Journalists Association (www.saja.org) encompass a range of approaches and engagements with the media in India and south Asia.

2 Recent works on satellite television in India include Page and Crawley (2001), Melkote (1998), and selected essays in Brosius and Butcher (1999).

3 S. V. Srinivas of the Center is also engaged in a comparative study of spectatorship for Telugu cinema and Hong Kong action cinema. See www.cscsban.org.

4 MTV first appeared in India on the original Star TV line-up in 1991 and mainly featured Western pop songs. It was replaced by the Star network's Channel V in 1994, which pioneered the "Indian-Western" hybrid sensibility and found widespread success among urban middle-class viewers. MTV India started operations in late 1996, and quickly outdid Channel V in its "Indianization" strategies.

5 Despite a small market presence, Indian pop music mainly began to achieve visibility and commercial success in the post-satellite-television era. "Made in India" was the first pop album to achieve sales comparable to film albums. For an excellent overview of the Indian music industry, see Manuel (1993).

6 David McCaughan (1998: March 4-10) writes that Asian youth are in a process of "rebelling in" to the middle class, and do not see their generational identity in oppositional terms to that of their parents. In India, the "liberalization" age cohort is being especially targeted by market researchers for its ostensible uninhibited ability to express its national pride through consumption, according to media planner Rama Bijapurkar (1998: March 4-10).

7 Quoted in Hussain, 1997: Aug. 6-12.

8 In addition to mainstream Indian advertising, another source for such triumphalism is the internet. Young Indians frequently email each other lists of India's claims to greatness: these range from "India has never invaded another country" to the "inventor of Hotmail is an Indian." I have also observed that Indian students in the US now include statistics on the Indian armed forces during their cultural events.

\section{References}

Ang, I. (1996). Living Room Wars: Rethinking Media Audiences for a Postmodern World. New York: Routledge.

Appadurai, A. (2000). "Grassroots Globalization and the Research Imagination." Public Culture 12(1): 1-19. 


\section{The Whole World is Watching Us}

Bijapurkar, R. (1998). A market in discontinuity. The Economic Times [online], available http://www.economictimes.com, accessed March 4-10.

Brosius, C. and Butcher, M., eds. (1999). Image Journeys: Audio-Visual Media and Cultural Change in India. New Delhi: Sage.

Butcher, M. (1999). "Parallel Texts: The Body and Television in India.” In C. Brosius and M. Butcher, eds., Image Journeys: Audio-Visual Media and Cultural Change in India. New Delhi: Sage, 165-98.

Chadha, K. and Kavoori, A. (2000). "Media Imperialism Revisited: Some Findings from the Asian Case." Media, Culture, and Society 22: 415-32.

Chen, K. (1998). “Introduction: The Decolonization Question.” In K. Chen, ed., Trajectories: Inter-Asia Cultural Studies. New York: Routledge, 1-53.

Dickey, S. (1996). "Consuming Utopia: Film Watching in Tamil Nadu." In C. Breckenridge, ed., Consuming Modernity: Public Culture in a South Asian World. Minneapolis: University of Minnesota, 131-5.

Gibson, T. (2000). "Beyond Cultural Populism: Notes Toward the Critical Ethnography of Media Audiences.” Journal of Communication Inquiry 24: 253-76.

Hussain, S. (1997). "V’Jaying On.” The Economic Times, Aug. 6-12, p. 8.

Juluri, V. (1998). "Globalizing Audience Studies: The Audience and its Landscape and Living Room Wars." Critical Studies in Mass Communication 15: 85-90.

Juluri, V. (2003). Becoming a Global Audience: Longing and Belonging in Indian Music Television. New York: Peter Lang.

Mankekar, P. (1999). Screening Culture, Viewing Politics: An Ethnography of Television, Womanhood, and Nation in Postcolonial India. Durham, NC: Duke University Press.

Manuel, P. (1993). Cassette Culture: Popular Music and Technology in North India. Chicago: University of Chicago Press.

McCaughan, D. (1998). "Hanging Out? That's Cool!” The Economic Times [online], available http://www.economictimes.com, accessed March 4-10.

McKinley, E. (1997). Beverly Hills 90210: Television, Gender and Identity. Philadelphia: University of Pennsylvania Press.

Melkote, S., ed. (1998). International Satellite Broadcasting in South Asia. New York: University Press of America.

Nandy, A. (1983). The Intimate Enemy: Loss and Recovery of Self under Colonialism. Delhi: Oxford University Press.

Nandy, A. (1998). "A New Cosmopolitanism: Toward a Dialogue of Asian civilizations.” In K. Chen, ed., Trajectories: Inter-Asia Cultural Studies. New York: Routledge, 142-9.

Natrajan, B. and Parmeswaran, R. (1997). "Contesting the Politics of Ethnography: Towards an Alternative Knowledge Production.” Journal of Communication Inquiry 21: 27-59.

Nightingale, V. (1996). Studying Audiences: The Shock of the Real. New York: Routledge. 


\section{Vamsee Juluri}

Page, D. and Crawley, W. (2001). Satellites over South Asia: Broadcasting, Culture, and the Public Interest. New Delhi: Sage.

Radhakrishnan, R. (1994). "Postmodernism and the Rest of the World." Organization 1: 305-40.

Rajagopal, A. (2000). "Hindutva at Play (Interviewed by Darryl D’Monte)." Frontline 17. Available at http://www.the-hindu.com/frontline.

Roach, C. (1997). "Cultural Imperialism and Resistance in Media Theory and Literary Theory." Media, Culture, and Society 19: 47-66.

Sinha, D. (2000). "Info-Age and Indian Intellectuals: An Unfashionable Poser." Economic and Political Weekly 4188-94.

Stromer-Galley, J. and Schiappa, E. (1998). "The Argumentative Burden of Audience Conjectures: Audience Research in Popular Culture Criticism." Communication Theory 8(1): 27-62.

Tomlinson, J. (1991). Cultural Imperialism: A Critical Introduction. Baltimore, MD: Johns Hopkins University Press.

Vasudeva, S. and Chakravarty, P. (1989). "The Epistemology of Indian Mass Communication Research.” Media, Culture, and Society 11: 415-33. 